\title{
The Existence Of The Village Secretary From Civil Servants In The Administration Of The Village Government (The Study in Sub-district of North Luwuk in Banggai District)
}

\author{
Nirwan Moh Nur ${ }^{1}$ dan Risno Mina ${ }^{2}$ \\ 1,2The Law Faculty of Muhammadiyah University of Luwuk Banggai

\section{nnirwanmnur@yahoo.co.id}

\begin{abstract}
The existence of village secretaries from civil servants is expected to make the village government management more effective, especially in the service to the community. However, as mentioned above, expectations in other perspectives need to be tested in the field. The village perspective as a community unit which is having an original autonomy based on its origin and custom, the presence of village secretaries from civil servant is certainly subjects to the norms of personnel in carrying out their duties and responsibilities. In the northern Banggai in Luwuk district, the village secretaries from civil servants are very helpful and have the ability to administer the public service administration and governance. But in the preparation of the annual work program and the village budgets, every year the village secretary is not optimal in carrying out their duties. The labor relation and the village secretary relationship with other tools in other villages in assisting the village head in order to strengthen the village autonomy and in order to improve the public services and in the development of village has proceeded well.
\end{abstract}

Keywords: Existence, Village Secretaries

\section{INTRODUCTION}

The existence of legal rules governing the field of village government is necessary very logical and fundamental in the development of rural sector which is part of the sub-system of local government, it is intended to provide the legal certainty in the field of village government in maintaining harmony/balance in facing the rate of growth and development of the national development. Esmi 
Wirassih ${ }^{1}$ said that it becomes one of the complex problems which faces and requires the legal instruments namely the administration of the village government. The village government as an extension agency of the central government has a strategic role that requires the regulations related to a village governance governing the village so that the wheels of governance run optimally. ${ }^{2}$

To regulate the field of village governance, the need for legal certainty in maintaining harmony/balance in facing the rate of growth and the development of national development. Jenpatar Simammora says that today's modern era, it can be said that a country is ideal and relevant when all series of state activities are based on the clear and firm legal mechanism. ${ }^{3}$

The rationale in governance arrangements is diversity, participation, indigenous autonomy and community empowerment. ${ }^{4}$ The spirit of reform has brought the impact of the amendment of Indonesian Republican Law number 22 of 1999 which was the replaced with the Indonesian Republican law number 32 of 2004 on local government. Then this law is replaced by Law no. 23 of 2014. The sign of this change gives the fresh condition to the changes of the local government and village administration system, where the responsibilities which

1 Esmi Wirassih, 2005, Pranata Hukum Sebagai Telaah Sosiologis, Semarang: Suryandanu Utama, hlm.30, dikutip oleh Kemas A. Somad, "Reformasi Birokrasi Desa Menuju Pemerintahan Desa Yang Demokratis,

2 Nina Karlina, "Pengangkatan Sekretaris Desa Menjadi PNS Dalam Mendukung Penyelenggaraan Pemerintahan Desa Di Kabupaten Cirebon" Jurnal Sosiohumanioar, Volume 16, Nomor 2, 2014, p.295

3 Jenpatar Simamora, "Tafsir Negara Hukum dalam Perspektif Undang-Undang Dasar Negara Republik Indonesia Tahun 1945", Jurnal Dinamika Hukum, Vol., 14, No.3, September 2014, Purwokerto: Fakultas Hukum, Universitas Jenderal Soedirman, p.548 dikutip juga Hardianto Djanggih, dan Kamri Ahmad, Effectiveness of Indonesian National Police Function Police on Banggai Regency Police Investigation (Investigation Case Study Year 2008-2017, Jurnal Dinamika Hukum, Volume 17, Nomor 2, 2017, p.152

4 Sri Hartini dan Abdul, A.N, "Pengisian Jabatan Sekretaris Desa Di Kabupaten Banyumas (Studi Tentang Kebijakan Pengisian Jabatan Sekretaris Desa", Jurnal Dinamika Hukum, Volume 8, Nomor 1, 2008, p.13 
embodied in the law's mission imply the practice of administering the local government especially the village government.

To support the fundamental change of the village administration, it has revoked the legal products of the ministerial level, the decree of the Home Affair Minister, and the instructions of the Interior Minister, replaced by the government Regulation no. 72 of 2005 on the village. ${ }^{5}$ The regulation of the village in the legislation has been replaced by the presence of Republic Indonesia in Law no. 6 of 2014 on the village. This is because one of the attention to the arrangements in the provision, namely with regard to the arrangement of the village's own device.

The appointment of the village secretaries into become a civil servant had a significant impact on the administration of the village government. According to the background, the problems in this research are: First, the state of the village secretary before it was appointed. Second, the situation of the village secretaries after being appointed as civil servant. And thirdly, the impact of the policy of the village secretaries appointing into civil servant on the administration of the village government. ${ }^{6}$

The position of the village secretary in the village administration as a village apparatus is the leader of the village bureaucracy consisting the heads of problematic affairs. Then who overshadowed the current position of the village secretary in Banggai district especially in northern Luwuk district is the hope as contained in Article 202 of the Republic Indonesian Law no. 23 of 2004. Although this law has been replaced, but practically the village secretary which

5 Dwi Astuti, "Persepsi Masyarakat Terhadap Pelaksanaan Undang-Undang Nomor 6 Tahun 2014 Tentang Desa Di Desa Bumiayu Pati" Jurnal Democratia, Volume 2, Nomor 1, 2014, p.36

M. Farid Ridha dan Sujianto, "Kabijakan Pengangkatan Sekretaris Desa Menjadi PNS" Jurnal Demokrasi Dan Otonomi Daerah Volume 11, Nomor 1 (2013), p.39 
comes from civil servant still exist. Thus, in the capacity as a civil servant, the rests on the expectations referred to the provision above.

It must be acknowledged that the burden of the village secretary's job is indeed very large as the bureaucratic and administrative leaders in order to support the village government tasks led by the village head. The above reality which may be the one of the practical considerations of making the law so as to form the norm of filling the position of village secretary filled by the civil servant. In addition, the existence of the village secretaries which should be held by the civil servants is expected that the village government management will be more effective, especially in the service of the community.

However, the expectations mentioned above, in other perspectives need to be field tested. In the village perspective as the legal community unity which has an original autonomy based on its origin and customs, the presence of the village secretary from the civil servants, is certainly subject to employment norms in carrying out their duties and responsibilities.

The fundamental issues in this study's assessment are; how is the existence of the village secretaries coming from the civil servant in performing their function of the administration and how is the community service is Luwuk sub-district of Banggai district?

\section{RESEARCH METHOD}

This research employs the empirical juridical approaches. Empirical law research is a law that is identified as a perpetrator of the pattern or understanding of social meaning. Using a juridical approach because this study stems from certain rules and regulations, this means that the principles contained in this particular legal rule are used to look at and examine the issue which will be studied. This empirical juridical approach was undertaken to describe the existence of village secretary from civil servants in performing the 
administrative and public service function in Luwuk sub-district of Banggai district and the relation work between the village secretary and other village apparatus in assisting the village head as the leader of the village government in the context of strengthening the village autonomy in order to improve the public services and the village development in Luwuk sub-district of Banggai district.

\section{DISCUSSION}

\section{A. The Existence of Village Secretaries Derived From The Civil Servant in Performing the Function of Administrators and Public Services}

The position of the village secretaries in the village government are as a village apparatus. The village secretary is the leader of the village bureaucracy composed of the heads of affairs. As the sound of Article 25 of the Republic Indonesia Law no. 6 of 2014 about the village, which says "the village government referred to an Article 23 is the village head or called by another name and who is assisted by the village apparatus or called by another name".

Then the village apparatus is as regulated in Article 48 of Indonesia Republic law number 6 year 2014 about the village, that is as follows:

1. Village secretaries

2. Regional executor, and

3. Technical implementers.

Based on the result of the research in the northern sub-district of Luwuk, the village secretary from civil servants is very helpful and has the ability to implement the administrative and service governance to the community. But in preparing the annual work program of the village each year and the village APB, the village secretary is not optimal in performing their duties.

The description above illustrates that the ability of the village secretary who comes from civil servants in the northern Luwuk sub-district, in carrying out 
the function as the administrator and the community service can be relatively said running optimally. The optimization of the village secretary function is supported by the steps taken by the government in northern Luwuk. This is as proposed by the northern Luwuk district head who stated that the existence of the secretaries from the civil servants since they were appointed, the local government through the district government has taken steps to improve the capacities as a civil servants who get the responsibility as the village secretary at the sub-district office. These responsibilities through several activities undertaken in the form of apprenticeship to all of the village secretaries in the sib-district office. The apprenticeship for the village secretaries is required in the framework of administrative learning and correspondence and familiarize the discipline of work in relation to the fulfillment of the office hours.

Thus, the optimization of the village secretary function is intended to be independent of the coaching efforts undertaken by the local government through the district government, as a form of responsibility for the implementation of the village government and the community service in the village, especially in northern Luwuk region.

\section{B. The Relationship and Work Relation Between the Village Secretaries and Other Village Apparatus in Assisting the Village Head}

Village governance is organized by the village government. While the village government itself is regulated in the provision of Article 25 of the Indonesian Republic law number 6 of 2014, as mentioned above that the village government is the village head assisted by the village apparatus. Talking about the village apparatus as described earlier, it is included the village secretary.

In this connection, the village secretary is placed as the assistant of the village head which is a subordinate of the village head. As the subordinate of the village head, then in carrying out his duties the village secretary is 
automatically responsible to the village head. Whereas in the relation to the other village apparatuses, when referring to the above provision, the existence of the village secretary against the other village apparatuses is as partner in assisting the village head. This can be seen in then provision of article 49 which are:

(1) Village apparatus as referred to article 48 shall assist the village head in carrying out his duties and authorities.

(2) Village apparatus referred to paragraph 1 shall be appointed by the village head after the consultation with the sub-district head on behalf of the regent/mayor.

(3) In performing their duties and authorities, the village apparatus referred to paragraph 1 shall be accountable to the village head.

The relation and working relationship between the village secretaries and other village apparatuses in assisting the village head as the head of the village administration is in the context of strengthening the village autonomy in order to improve the community service and village development.

From the result of research conducted in the north of Luwuk district, the relationship and work relations between the village secretary and the village head and also the other village apparatus have been running optimally. However, especially with the ability of the village secretary to carry out the function to bridge the coordination relationship between the village head and BPD in making the village regulation is not in the optimal function.

Whereas in fact, the existence of the village secretary as bureaucratic leaders at the village level is required to act as administrators and facilitators in preparing the policy formulation and governance, village development and community empowerment. This condition becomes the duty and the responsibility of the village government headed by the village head and assisted by the ranks of the village apparatus and also the village secretary. 
As a system of administration of a village governments which have the autonomy, it requires the participations and the involvement of other institutions in the village, the other institution and most importantly is the village consultative body (BPD) as a forum for democracy and community representatives in the village. The village autonomy in this case is intended in order to regulate and manage the village households, reflected through the ability of the village in order to the regulation, regulate the implementation of the village, explore the potential that exist and organize the life together in the village community itself.

The reflection of the village autonomy itself is further articulated through the ability of all elements of the village government administrations in formulating and defining the policies and regulations in the case of village regulations as the legislation at the village level, jointly established between the village administration headed by the village heads and assisted by all village apparatus including the village secretaries and BPD as the representative institutions at the village level. Hence the presence of the village secretary as bureaucratic leader at the village level is required for his role in administrating, planning and facilitating the task of the government in order to assist and support the village head as the government leader in village level, in relation to strengthening and establishing the cooperation and coordination with other institutions in the village. Through this relationship is expected to be born the policies and rules in strengthening the village autonomy itself.

The above conditions are based on searching empirical data that the writer find in the field and evidenced by the lack of the productivity of village regulation in several villages which become the object of the study. The fact that the village regulations are only the village regulation on the village income and expenditure budget (APBDES). This is because it is a must for every village in order to legalize the source of income and financing derived from assistance 
through the allocation of the village fubd and the share of taxes and user chargers that are the village entitlement granted by the district or upper level government.

\section{SUMMARY}

Based on the description above, it can be concluded that the village secretaries who comes from civil servant located in the northern Luwuk of Banggai district is very helpful and have the ability in implementing the governance administration and services to the community. But in the preparation of the annual work program and the village APB, the village secretary is not optimal in performing their duties. Then the relationship and work relation between the village secretary and other village apparatus in assisting the village head government in order to strengthen the village autonomy and to improve the public service and village development has been running optimal.

\section{BIBLIOGRAPHY}

Wirassih, Esmi (2005) Pranata Hukum Sebagai Telaah Sosiologis, Semarang: Suryandanu Utama.

Somad, Kemas A. (2012) "Reformasi Birokrasi Desa Menuju Pemerintahan Desa Yang Demokratis, Jurnal Masalah-Masalah Hukum, 41 (4).

Karlina, Nina (2014) "Pengangkatan Sekretaris Desa Menjadi PNS Dalam Mendukung Penyelenggaraan Pemerintahan Desa Di Kabupaten Cirebon" Jurnal Sosiohumanioar, 16 (2).

Simamora, Jenpatar (2014) "Tafsir Negara Hukum dalam Perspektif UndangUndang Dasar Negara Republik Indonesia Tahun 1945”, Jurnal Dinamika Hukum, 14 (3) 
Djanggih, Hardianto dan Kamri Ahmad, (2017) Effectiveness of Indonesian National Police Function Police on Banggai Regency Police Investigation (Investigation Case Study Year 2008-2017, Jurnal Dinamika Hukum, 17 (2)

Astuti, Dwi (2014) "Persepsi Masyarakat Terhadap Pelaksanaan UndangUndang Nomor 6 Tahun 2014 Tentang Desa Di Desa Bumiayu Pati" Jurnal Democratia, 2 (1)

Hartini, Sri dan Abdul, A.N, (2008) "Pengisian Jabatan Sekretaris Desa Di Kabupaten Banyumas (Studi Tentang Kebijakan Pengisian Jabatan Sekretaris Desa", Jurnal Dinamika Hukum, 8 (1).

Ridha, M. Farid dan Sujianto, (2013) "Kabijakan Pengangkatan Sekretaris Desa Menjadi PNS" Jurnal Demokrasi Dan Otonomi Daerah. 11 (1).

\section{Sources of Legislation}

Undang-Undang Dasar Negara Republik Indonesia Tahun 1945

Undang-Undang Republik Indonesia Nomor 32 Tahun 2004 Tentang Pemerintahan Daerah.

Undang-undang Republik Indonesia Nomor 6 Tahun 2014 Tentang Desa Undang-Undang Republik Indonesia Nomor 23 Tahun 2014 Tentang Pemerintahan Daerah

Undang-Undang Republik Indonesia Nomor 9 Tahun 2015 Tentang Perubahan Kedua Atas Undang-Undang Nomor 23 Tahun 2014 Tentang Pemerintahan Daerah

Peraturan Pemerintah Republik Indonesia Nomor 72 Tahun 2005 Tentang Desa. 